\title{
ECOLOGY
}

\section{The influence of fish culture in floating net cages on microbial indicators of water quality}

\author{
Gorlach-Lira, K. ${ }^{a^{*}}$, Pacheco, C. ${ }^{a}$, Carvalho, L.C.T. ${ }^{a}$, Melo Júnior, H.N. ${ }^{b}$ and Crispim, M.C. ${ }^{c}$ \\ ${ }^{a}$ Universidade Federal da Paraíba, Centro de Ciências Exatas e da Natureza, \\ Departmento de Biologia Molecular, João Pessoa - PB, Brazil \\ ${ }^{b}$ Universidade Regional do Cariri, Laboratório de Limnologia e Aquicultura, \\ Departamento de Ciências Biológicas, Crato - CE, Brazil \\ ${ }^{c}$ Universidade Federal da Paraíba, Centro de Ciências Exatas e da Natureza, \\ Departamento de Sistemática e Ecologia, João Pessoa - PB, Brazil \\ e-mail:kglira@yahoo.com \\ Received: February 2, 2012 - Accepted: September 28, 2012 - Distributed: August 31, 2013
}

(With 2 figures)

\begin{abstract}
This work was carried out to analyse the microbiological parameters of the water quality of a reservoir used for the irrigation and culture of tilapia (Oreochromis niloticus) in floating net cages. The physico-chemical parameters, counts of mesophilic total aerobic bacteria, total and thermotolerant coliforms and fecal streptococci, and the presence of Escherichia coli in samples of water collected in three sites of the reservoir (pre-culture site, culture site, post-culture site) were analysed. The levels of ammonia $(0.047-0.059 \mathrm{mg} / \mathrm{L})$, nitrite $(0.001-0.021 \mathrm{mg} / \mathrm{L})$ and total phosphorus $(0.050-$ $0.355 \mathrm{mg} / \mathrm{L})$ in the water did not show significant differences $(\mathrm{p}>0.05)$ between sampling sites. The levels of total bacteria in the water varied between $1.3 \times 10^{4}$ and $67.3 \times 10^{4} \mathrm{CFU} / 100 \mathrm{~mL}$. The MPN values of thermotolerant coliforms $(<930 \mathrm{MPN} / 100 \mathrm{~mL})$ were within values recommended for water used for fish culture and/or irrigation. The presence of $E$. coli and fecal streptococci were verified in $48 \%$ and $56 \%$ of analysed samples, respectively. The site with floating net cages showed more samples contaminated with $E$. coli and fecal streptococci than other sampling points.
\end{abstract}

Keywords: fish culture, tilapia, cage, coliforms, faecal streptococci.

\section{Influência da piscicultura em tanques-rede sobre os microrganismos indicadores da qualidade de água}

\section{Resumo}

Este trabalho foi realizado para analisar os parâmetros microbiológicos da qualidade da água de um reservatório destinado a irrigação e à cultivo de tilapia do Nilo (Oreochromis niloticus) em tanques redes. Foi realizada análise de parâmetros físico-químicos, quantificação de bactérias totais aeróbias mesófilas, coliformes totais e termotolerantes, estreptococos fecais e a deteç̧ão de E. coli em amostras de água coletada em três pontos distintos do açude (pré-cultivo, cultivo, pós-cultivo). Os níveis de amônia (0,047-0,059 mg/L), nitrito (0,001-0,021 mg/L) e fósforo total $(0,050-0,355 \mathrm{mg} / \mathrm{L})$ na água não apresentaram diferenças significativas $(\mathrm{p}>0.05)$ entre os pontos de coleta. As contagens de bactérias aeróbias mesófilas variaram entre $1,3 \times 10^{4}$ e 67,3 x 10 UFC/100 mL nas amostras de água. O NMP de coliformes termotolerantes $(<930 \mathrm{NMP} / 100 \mathrm{~mL})$ se apresentou dentro do limite permitido para águas doces destinadas a piscicultura e/ou irrigação. A presença de E. coli foi constatada em $48 \%$ e de estreptococos fecais em $56 \%$ das amostras de água analisadas. O local de cultivo de tilápia em tanques-rede apresentou maior número de amostras contaminadas com E. coli e estreptococos fecais que outros pontos de amostragem.

Palavras-chave: piscicultura, tanques-rede, tilápia, coliformes, estreptococcus fecais.

\section{Introduction}

The intensive culture of fish in cages, such as floating net cages is widespread around the world, and is indicated as one of the major methods for intense fish production in the tropics (Outtara et al., 2003; Liao et al., 2004). Over the last decade, cage aquaculture in Brazil has expanded in an expressive way, generating substan- tive income and an increase in the production and exportation of fish. According to the FAO (2009), the freshwater fish produced in fish culture in Brazil constituted for $70 \%$ of the total aquaculture production.

The environmental impact of waste (fish faeces, uneaten food, bacterial biomass) from the fish culture industry, notably from cage fish farms, is an increasing 
issue of concern around the world. The intensive fish culture in cages can lead to the eutrophisation of water bodies and to the emergence of deleterious effects on the water quality, such as the blooms of toxic cyanobacteria that are harmful for wildlife and humans. There are several works on the effect of fish culture in cages on water quality (Ntengwe et al., 2008; Azevedo et al., 2011; Degefu et al., 2011; Schenone et al., 2011). Cage fish farming is usually performed in small water bodies such as fish ponds and reservoirs, which are often used for plant irrigation. In fish farming projects and irrigation reservoirs, it is essential to control the physical, chemical and biological variables of the water that may affect the survival and growth of fish, as well as the irrigated plant development and human health (Lachi and Sipaúba-Tavares, 2008).

Successful fish farming in ponds depends on the physical, chemical and biological characteristics of the water and the nutrition management of the aquaculture species. All of these factors in fish farming ponds and lakes are inter-related and require careful and constant monitoring to avoid contamination and/or degradation of the environment. Special attention must be paid to cyanobacteria blooms, which are symptomatic of eutrophication in productive lakes, since they may produce cyanotoxins (Funari and Testai, 2008; Semyalo et al., 2010) which are toxic to vertebrates and can affect human health through direct contact or consumption of contaminated water, fish or plants. Caging aquaculture may also cause other impacts on aquatic environments, such as the destruction of natural habitats and alterations in the structure and dynamics of local organisms, as well as trophic changes (Agostinho et al., 2008; Strictar-Pereira et al., 2010; Dias et al., 2012).

Microorganisms have a very important function in water bodies, since they participate in the transformation of the nutrients, the nutrition of animals, disease control and they may affect various parameters of water quality, such as dissolved oxygen, $\mathrm{pH}$ and ammonia (Moriarty, 1997).

The indicator microorganisms such as total and thermotolerant coliforms, Escherichia coli and faecal streptococci, are commonly used to assess the contamination level of water and food. The faecal streptococci and, mainly, the enterococos constitute for one of the most efficient indicators for faecal contamination in water (APHA, 1998).

In this work we examined the reservoir used for the irrigation of sugar cane plantation and for small-scale culture of Nile tilapia (Oreochromis niloticus) in floating net cages in the northeast of Brazil. We analysed some microbiological and physico-chemical parameters of the reservoir to assess the influence of fish cage farming on the water quality.

\section{Materials and Methods}

\subsection{Study area}

The reservoir Padre Azevedo with a surface area of $2.32 \mathrm{~km}^{2}$ is located in the municipal district of Sape in the state of Paraíba, Brazil $\left(07^{\circ} 02^{\prime} 20^{\prime \prime} \mathrm{S}\right.$ and $\left.35^{\circ} 11^{\prime} 15^{\prime \prime} \mathrm{W}\right)$ (Figure 1). The regional climate is classified as humid
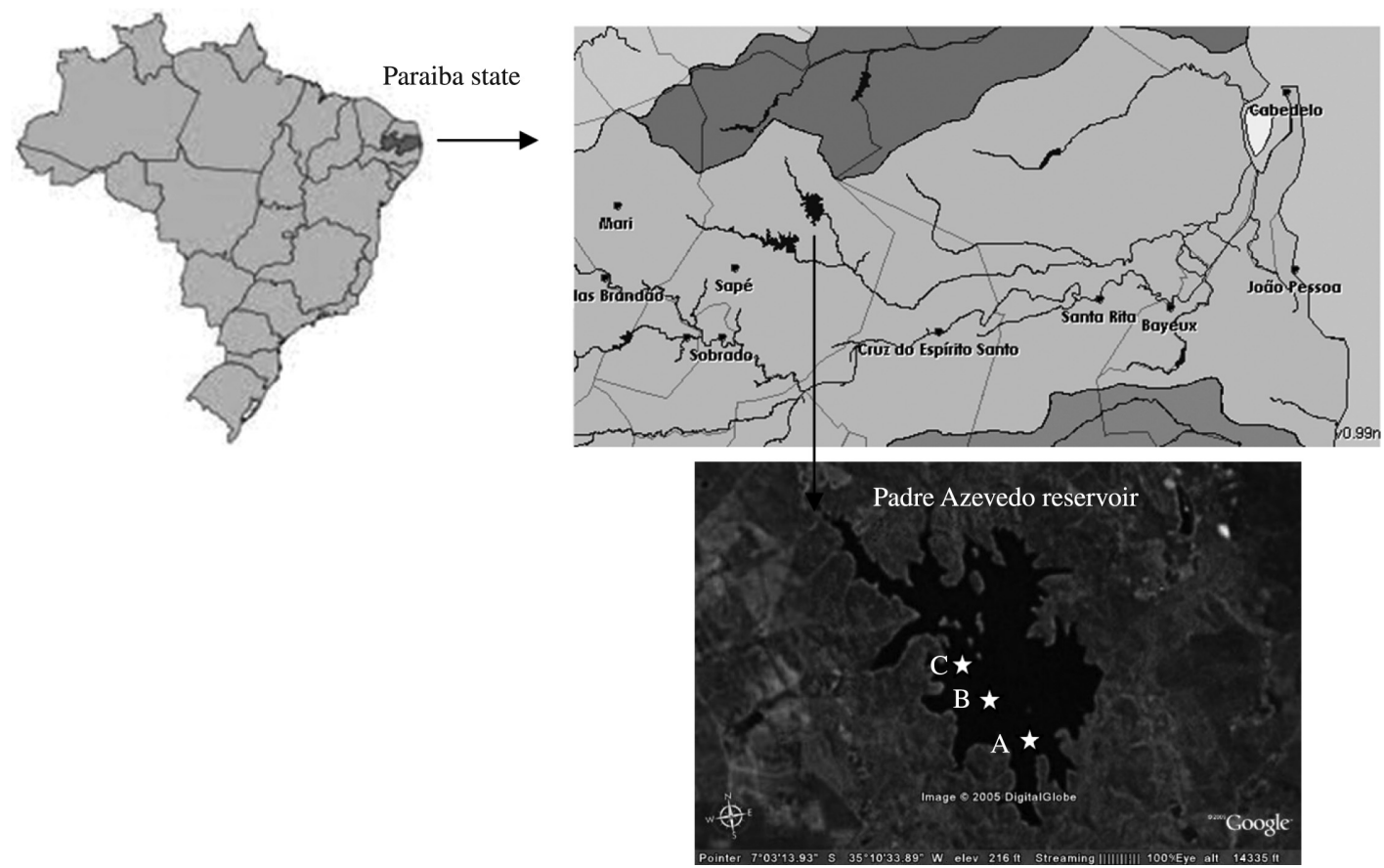

Figure 1 - Localization of reservoir Padre Azevedo at the Paraíba state (Brazil) and the sampling sites: A - pre-cultivation site; $\mathrm{B}$ - cultivation of tilapia in net cages; $\mathrm{C}$ - post-cultivation site. 
tropical, and annually receives an average rainfall of $900 \mathrm{~mm}$, with two distinct seasonal periods of precipitation: a dry season that normally extends between September and February, and a rainy season from March to August. During the year of this study (2008) the monthly precipitations of the rainy season varied between 150 and $200 \mathrm{~mm}$, and in the dry season between 10 and $50 \mathrm{~mm}$.

The reservoir Padre Azevedo was mainly used to supply water for the irrigation of the sugar cane plantation, and fish farming in net cages was a valuable additional activity. Initially, the reservoir contained 300 floating net cages for the production of Nile tilapia (Oreochromis niloticus), with a volume of $4 \mathrm{~m}^{3}$ each, but at present the number of cages is lower. The cages were filled with 800 fish of $70 \mathrm{~g}$, with a density of $200 \mathrm{fish} / \mathrm{m}^{3}$, and later three gradings were carried out to reduce the amount of fish to $600-700$, with a density of 150 $175 \mathrm{fish} / \mathrm{m}^{3}$.

\subsection{Sampling and the physicochemical analysis of water}

The water samples were collected in three sites from the reservoir at $1.0 \mathrm{~m}$ depth : A - pre-cultivation site; B cultivation site with fish cages; $\mathrm{C}$ - post-cultivation site (Figure 1), every two months during the year of 2008. The water samples in 2-litre pet bottles were maintained at $4{ }^{\circ} \mathrm{C}$ for up to 24 hours.

The following physico-chemical parameters of water were analysed: temperature, $\mathrm{pH}$, amount of ammonia, nitrite, total phosphorus and dissolved oxygen according to the methods described by Koroleff (1976) and APHA (1998).

\subsection{Microbiological analyses of water samples}

Decimal dilutions of water samples were made with saline solution $0.9 \%$ and plated on selective media. Counts of total aerobic mesophilic bacteria were done on the Plate Count Agar (PCA) (Difco). The plates were incubated at $30{ }^{\circ} \mathrm{C}$ for 5 days. The enumeration of total and thermotolerant coliforms were realised by the Most Probable Number (MPN) technique, according to APHA (1998), using the following media: the Lauril Sodium Sulfate Broth (presumptive test for the total coliforms); the Lactose Bile 2\% Brilliant Green Broth (confirmative test for the total coliforms and the presumptive for thermotolerant coliforms) and the Escherichia coli Broth (confirmation for the thermotolerant coliforms). The presence of $E$. coli was determined on the fluorogenic medium MUG (Himedia). The quantification of faecal streptococci was done through the MPN technique using the Dextrose Azide Broth (APHA, 1998), and the confirmation of the presence of faecal streptococci was carried out on Enterococos Pfizer medium (PSE, Himedia).

\subsection{Statistical analysis}

The one-way analysis of variance (ANOVA) was performed on the data of bacterial density and physicochemical variables using Statistica (version 5) software.
Mean values and standard errors were generated for each microbial group and physical and chemical parameter.

\section{Results}

The results of the physico-chemical parameters of the water samples from the three sampling points on the fish farm reservoir are presented in Table 1. The average temperature of water in all sampling points varied between $27.8^{\circ} \mathrm{C}$ and $28.1^{\circ} \mathrm{C}$. The $\mathrm{pH}$ values showed strong fluctuations over the study period (Table 1 ), especially in the culture site (6.2-10.0). Throughout the experiment, the amount of ammonia, nitrite, phosphorus and dissolved oxygen in the reservoir water did not differ significantly between sampling sites $(\mathrm{p}>0.05)$. The levels of ammonia varied from 0.047 to $0.597 \mathrm{mg} / \mathrm{L}$, with higher means for the culture and post-culture sites (B and C) (Table 1). The nitrite varied from 0.001 to $0.021 \mathrm{mg} / \mathrm{L}$, with similar means for all sites. The total phosphorus ranged from 0.050 to $0.355 \mathrm{mg} / \mathrm{L}$, and its highest concentrations were registered between February and August (rainy season). The values of dissolved oxygen slightly varied between the analysed sites, with an average values of between 7.1 and $8.4 \mathrm{mg} / \mathrm{L}$ (Table 1).

Counts of total heterotrophic bacteria ranged from $1.3 \times 10^{4}$ to $67.3 \times 10^{4} \mathrm{CFU} / 100 \mathrm{~mL}$ of water (Table 2). The lowest numbers of bacteria were observed at the end of the rainy season (August) in all sampling sites. Average counts of bacteria were higher in the fish culture site (site B - $34.2 \mathrm{CFU} / 100 \mathrm{~mL}$ ) than in the pre- and postculture sites (Table 2).

The total coliforms were found in almost all samples of the reservoir and their numbers varied between 70 and $4600 \mathrm{MPN} / 100 \mathrm{~mL}$ in the period from March to November, 2008 (Table 3). The total coliforms number was several times higher in January than in other months. The MPN values of thermotolerant coliforms in water samples were within the limits for the fresh water that can be used for fish farming and irrigation (1000 MPN/100 mL), however one sample collected at the culture site showed a value (930 MPN/100 mL) close to the permitted limit (Table 3). Site B (culture) was characterised by a higher number of samples with thermotolerant coliforms and higher numbers of these bacteria (Table 4, Figure 2). The lowest numbers of thermotolerant coliforms were observed in the water of the pre-cultivation site (site A), where only two samples showed a presence of these bacteria (40 MPN/100 mL).

The presence of $E$. coli was verified in $48 \%$ of the water samples (Table 4, Figure 2), and site B (fish culture) showed a higher number of positive samples. E. coli was detected in $1 \mathrm{~mL}$ of water in all positive samples, with the exception of one collected in site B $\left(10^{-1}\right.$ dilution) (Table 4).

The presence of faecal streptococci was observed in $56 \%$ of analysed samples and their numbers varied from 23 to $240 \mathrm{MPN} / 100 \mathrm{~mL}$ (Table 3, Figure 2). The postculture site showed more samples contaminated with fecal streptococci (71\%). 
Table 1 - Means, medians, minimum and maximum values of temperature, $\mathrm{pH}$, ammonia, nitrite, total phosphorus, dissolved oxygen in water of reservoir with fish cage farming.

\begin{tabular}{|c|c|c|c|}
\hline & Site A* & Site B & Site C \\
\hline & \multicolumn{3}{|c|}{ Temperature $\left({ }^{\circ} \mathrm{C}\right)$} \\
\hline Mean & 27.8 & 27.9 & 28.1 \\
\hline Standard deviation & 1.15 & 1.37 & 1.54 \\
\hline Median & 28.0 & 28.0 & 28.0 \\
\hline \multirow[t]{2}{*}{ Min-Max } & $26.0-29.0$ & $26.0-30.0$ & $26.0-30.0$ \\
\hline & \multicolumn{3}{|c|}{$\mathrm{pH}$} \\
\hline Mean & 8.42 & 8.16 & 8.83 \\
\hline Standard deviation & 0.99 & 1.56 & 1.04 \\
\hline Median & 8.50 & 8.40 & 9.00 \\
\hline \multirow[t]{2}{*}{ Min-Max } & $7.0-9.6$ & $6.2-10.0$ & $7.5-9.8$ \\
\hline & \multicolumn{3}{|c|}{ Ammonia (mg/L) } \\
\hline Mean & 0.141 & 0.221 & 0.233 \\
\hline Standard deviation & 0.148 & 0.207 & 0.203 \\
\hline Median & 0.079 & 0.078 & 0.077 \\
\hline \multirow[t]{2}{*}{ Min-Max } & $0.047-0.451$ & $0.051-0.535$ & $0.069-0.597$ \\
\hline & \multicolumn{3}{|c|}{ Nitrite $(\mathrm{mg} / \mathrm{L})$} \\
\hline Mean & 0.004 & 0.005 & 0.004 \\
\hline Standard deviation & 0.007 & 0.007 & 0.005 \\
\hline Median & 0.002 & 0.002 & 0.002 \\
\hline \multirow[t]{2}{*}{ Min-Max } & $0.001-0.019$ & $0.001-0.021$ & $0.001-0.014$ \\
\hline & \multicolumn{3}{|c|}{ Total phosphorus (mg/L) } \\
\hline Mean & 0.194 & 0.209 & 0.234 \\
\hline Standard deviation & 0.082 & 0.103 & 0.093 \\
\hline Median & 0.200 & 0.205 & 0.280 \\
\hline \multirow[t]{2}{*}{ Min-Max } & $0.070-0.300$ & $0.050-0.330$ & $0.125-0.355$ \\
\hline & \multicolumn{3}{|c|}{ Dissolved oxygen $(\mathrm{mg} / \mathrm{L})$} \\
\hline Mean & 7.07 & 8.36 & 8.14 \\
\hline Standard deviation & 4.12 & 4.79 & 5.96 \\
\hline Median & 7.50 & 7.50 & 7.50 \\
\hline Min-Max & $2.50-14.00$ & $3.50-17.50$ & $2.50-20.00$ \\
\hline
\end{tabular}

*A - pre-cultivation site; B - cultivation of tilapia in net cages; C - post-cultivation site.

Table 2 - Counts of mesophilic total bacteria in water samples of reservoir with fish cage farming.

\begin{tabular}{lcccccccc}
\hline Site* & Jan. & Mar. & May & June & Aug. & Sept. & Nov. & Mean \pm S.D. \\
\hline A & \multicolumn{7}{c}{ CFU } & $\mathbf{1 0} \mathbf{4} / \mathbf{1 0 0} \mathbf{~ m L}$ \\
B & 40.0 & 25.7 & 67.3 & 45.0 & 2.0 & 53.3 & 6.0 & $27.6 \pm 24.20$ \\
C & 57.0 & 15.7 & 47.7 & 26.3 & 1.3 & 40.0 & 5.0 & $34.2 \pm 21.48$ \\
\hline
\end{tabular}

*A - pre-cultivation site; B - cultivation of tilapia in net cages; C - post-cultivation site. S.D. - Standard deviation.

\section{Discussion}

The water quality of the net cages environment directly influences the productivity and the sanity of the fish (Kubitza, 2003; Sapkota et al., 2008). Theoretically, fish farming in cages in eutrophic environments is predis- posed to alterations in the function of high concentrations of nutrients; among them an increase in the eutrofization process, $\mathrm{pH}$ changes, and the possibility of increasing the toxicity of the non-ionized ammonia $\left(\mathrm{NH}_{3}\right)$ and nitrite $\left(\mathrm{NO}_{2}\right)$. In the reservoirs of the Brazilian northeast, high temperatures can catalyse those processes turning them 
Table 3 - The most probable numbers (MPN/100 mL) of indicator bacteria in water samples of reservoir with fish cage farming.

\begin{tabular}{|c|c|c|c|c|c|c|c|}
\hline Site* & Jan. & Mar. & May & June & Aug. & Sept. & Nov. \\
\hline \multicolumn{8}{|c|}{ Total coliforms } \\
\hline A & 150000 & 90 & 150 & 230 & 430 & 230 & 70 \\
\hline B & 240000 & N.D. & 430 & 430 & 4600 & 140 & 70 \\
\hline $\mathrm{C}$ & 150000 & 280 & 150 & 930 & 2400 & 750 & 750 \\
\hline \multicolumn{8}{|c|}{ Thermotolerant coliforms } \\
\hline A & 40 & N.D. & N.D. & 40 & N.D. & N.D. & N.D. \\
\hline B & 430 & N.D. & 930 & 230 & 40 & 30 & 70 \\
\hline $\mathrm{C}$ & 90 & N.D. & 40 & N.D. & N.D. & 210 & 90 \\
\hline \multicolumn{8}{|c|}{ Faecal streptococci } \\
\hline A & 93 & 93 & N.D. & 75 & 23 & 93 & 23 \\
\hline $\mathrm{B}$ & 210 & 23 & N.D. & 23 & 23 & 93 & 23 \\
\hline $\mathrm{C}$ & 240 & 23 & 4 & 75 & 23 & 23 & 23 \\
\hline
\end{tabular}

*A - pre-cultivation site; B - cultivation of tilapia in net cages; C - post-cultivation site. N.D. - Not detected.

Table 4 - The presence (+) or absence (-) of E. coli and faecal streptococci in water samples of reservoir with fish cage farming.

\begin{tabular}{lccccccc}
\hline Site* & Jan. & Mar. & May & June & Aug. & Sept. & Nov. \\
\hline A & \multicolumn{7}{c}{ Escherichia coli } \\
B & $+(1 \mathrm{~mL})$ & - & - & $+(1 \mathrm{~mL})$ & - & - & - \\
C & $+(1 \mathrm{~mL})$ & - & $+\left(10^{-1}\right)$ & $+(1 \mathrm{~mL})$ & $+(1 \mathrm{~mL})$ & - & - \\
\hline & $+(1 \mathrm{~mL})^{\mathrm{a}}$ & - & $+(1 \mathrm{~mL})$ & - & - & - & $+(1 \mathrm{~mL})$ \\
\hline A & - & $+(1 \mathrm{~mL})$ & - & $+\left(10^{-1}\right)$ & $+(1 \mathrm{~mL})$ & $+(1 \mathrm{~mL})$ & - \\
B & - & - & - & $+(10 \mathrm{~mL})$ & - & $+(1 \mathrm{~mL})$ & $+(10 \mathrm{~mL})$ \\
C & - & - & $+(10 \mathrm{~mL})$ & $+\left(10^{-1}\right)$ & $+(1 \mathrm{~mL})$ & $+(10 \mathrm{~mL})$ & $+(10 \mathrm{~mL})$ \\
\hline
\end{tabular}

*A - pre-cultivation site; B - cultivation of tilapia in net cages; C - post-cultivation site. ${ }^{\mathrm{a}}$ - the last dilution or direct inoculum.

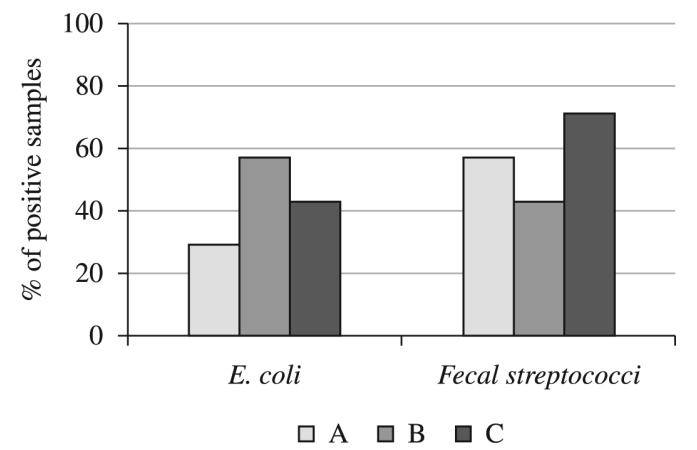

Figure 2 - Percentage of water samples contaminated with E. coli and fecal streptococci. A - pre-cultivation site; B cultivation of tilapia in net cages; $\mathrm{C}$ - post-cultivation site.

into more evident and frequent processes. The dynamics of nutrients, such as ammonia and nitrite is important for fish farming, especially in the reservoirs in the northeast of Brazil, because of the tropical climate and the presence of alkaline water. The interactions of these environmental factors can influence fish production by increasing the rate of alimentary conversion, reducing the weight gain and leaching of a higher quantity of nutrients into the environment.

During the study of Padre Azevedo reservoir the amount of ammonia, nitrite, phosphorus and dissolved oxygen in the water were similar for all sampling sites. The values of the ammonia observed in the reservoir were lower than the values that are considered harmful to the fish according to Carmo et al. (2008). Cardoso Filho et al. (2010) registered similar nitrite values in the water of fish farming effluents used for irrigation. Usually, as in the present work, low values of phosphorus are observed in the tanks with Nile tilapia culture (Baccarin and Camargo, 2005). 
Physico-chemical parameters of the water, such as $\mathrm{pH}$, nutrients and presence of toxic compounds may influence the density of bacterial populations. The importance of the microbial population in the reservoirs used for fish farming and irrigation can be resumed by its influence on the amount and diversity of bacteria in the fish during capture, handling and processing, as well as in the microbial contamination of food produced in agriculture under irrigation.

The levels of total mesophilic aerobic bacteria serve as support in the evaluation of the water in respect to the decomposing activity. Bacterial counts in the water analysed were in the range of $10^{4}$ to $10^{5} \mathrm{CFU} / 100 \mathrm{~mL}$. These results were lower than values recorded by Ntengwe and Edema (2008) in the order of $10^{6} \mathrm{CFU} / \mathrm{mL}$ of fishing culture pond water, but higher than those observed by Ahmed and Naim (2003) in the tilapia culture pond $\left(10^{3}\right.$ $10^{4} \mathrm{CFU} / \mathrm{mL}$ ).

Average counts of bacteria were higher in the site of fish culture then in the pre- and post-culture sites of the Padre Azevedo reservoir. Similarly, the culture site was characterised by higher numbers of thermotolerant coliforms and E. coli. However, the contamination level of faecal streptococci was higher in the post-culture site.

The relatively high numbers of bacteria observed in the reservoir reflect the nature of the cultivation of fish in net cages, which uses a considerable volume of alimentary inputs in the reduced area, with a consequent release of high quantities of alimentary residues and metabolites to the environment that can strongly influence the microbiological quality of water. Gondwe et al. (2011) observed that nutrient losses from cages to the surrounding environment in the order of $81-91 \%$ for $\mathrm{C}, 59-80 \%$ for $\mathrm{N}$ and $85-92 \%$ for $\mathrm{p}$, indicating the importance of cage aquaculture as a new source of nutrients, not only locally, but on a lake-wide basis, may stimulate microbial populations. As a consequence, the quality of commercialised fish can be committed due to the high contamination of pathogenic bacteria or saprophytic bacteria that accelerates the deterioration process of the fish.

Furthermore, the high temperature of the water observed in the tropics and the neutral and alkaline $\mathrm{pH}$ are favourable for the growth of bacteria. Such conditions were observed in the reservoir analysed in this work, where the water temperature ranged from 26 to $30^{\circ} \mathrm{C}$ and the majority of samples showed a $\mathrm{pH}$ over 8.0 during the period of study.

Our results showed that the water quality parameters of the Padre Azevedo reservoir were within the limits recommended for the production of fish and irrigation. However, the presence of $E$. coli was verified in $48 \%$ and faecal streptococci in $56 \%$ of the water samples, indicating the potential risks of contamination of the fish and plants when irrigated with polluted water. Santos et al. (2012) also observed the presence of total coliforms and Escherichia coli in the water of all six studied fish farms in Maranhão State (Brazil), and Alexopoulos et al. (2011) detected faecal coliforms and streptococci in all water samples from different Greek sea fish farms.
As shown in the present and other work, aquaculture environments are characterised by fluctuations of physico-chemical parameters and microbiological indicators caused by different nutrient loads, trophic changes, climatic characteristics, etc. (Baccarin et al., 2005; Degefu et al., 2011; Santos et al., 2012), and therefore special attention should be paid to the frequency of limnological and sanitary aspects of the water. Fish farming in the reservoirs used for irrigation may benefit aquaculture systems integrated with agriculture (Behera et al., 2012), however, there is a need to apply monitoring programmes regarding not only the physico-chemical parameters, but also the analysis of cyantoxins and microbiological indicators that are rarely included in the monitoring of the fish farm water quality. The microbial and phytoplankton dynamics in such sensitive ecosystems should be under constant control and frequent monitoring by using sensitive indicators.

\section{Acknowledgments}

The authors thank the Conselho Nacional de Pesquisa (CNPq), Brazil, for financial support.

\section{References}

ALEXOPOULOS, A., PLESSAS, S., VOIDAROU, C., NOUSSIAS, H., STAVROPOULOU, E., MANTZOURANI, I., TZORA, A., SKOUFOS, I. and BEZIRTZOGLOU, E., 2011. Microbial ecology of fish species ongrowing in Greek sea farms and their watery environment. Anaerobe, vol. 17, p. 264-266.

AGOSTINHO, AA., PELICICE, FM. and GOMES, LC., 2008. Dams and the fish fauna of the Neotropical region: impacts and management related to diversity and fisheries. Brazilian Journal of Biology, vol. 68, no. 4, p. 1119-1132.

AHMED, HA. and NAIM, U., 2003. Quantitative and qualitative studies on bacterial flora of hybrid tilapia (Oreochromis niloticus x $O$. aureus) cultured in earthen ponds in Saudi Arabia. Aquaculture Research, vol. 34, p. $43-48$.

American Public Health Association - APHA, 1998. Standard methods for the examination of water and wastewater. 20th ed. Washington: APHA.

AZEVEDO, PA., PODEMSKI, CL., HESSLEIN, RH., KASIAN, SEM., FINDLAY, DL. and BUREAU, DP., 2011. Estimation of waste outputs by a rainbow trout cage farm using a nutritional approach and monitoring of lake water quality. Aquaculture, vol. 311, p. 175-186.

BACCARIN, AE. and CAMARGO, AFM., 2005. Characterization and evaluation of the impact of feed management on the effluents of Nile tilapia (Oreochromis niloticus) culture. Brazilian Journal of Biology and Biotechnology, vol. 48, p. 81-90.

BEHERA, UK., PANIGRAHI, P. and SARANGI, A., 2012. Multiple water use protocols in integrated farming system for enhancing productivity. Water Resources Management, vol. 26, p. 2605-2623.

CARDOSO FILHO, R., CAMPECHE, DFB. and PAULINO, RV., 2010. Tilápia em reservatório de água para irrigação e avaliação da qualidade de água. Agrária, vol. 5, p. 117122.

CARMO, JL., FERREIRA, DA., SILVA JÚNIOR, RF., SANTOS, RMS. and CORREIA, ES., 2008. Crescimento de 
três linhagens de tilápia sob cultivo semi-intensivo em viveiros. Caatinga, vol. 21, p. 20-26.

DEGEFU, F., MENGISTU, S. and SCHAGERL, M., 2011. Influence of fish cage farming on water quality and plankton in fish ponds: A case study in the Rift Valley and North Shoa reservoirs, Ethiopia. Aquaculture, vol. 316, p. 129135.

DIAS, JD., SIMÕES, NR. and BONECKER, CC., 2012. Zooplankton community resilience and aquatic environmental stability on aquaculture practices: a study using net cages. Brazilian Journal of Biology, 2012, vol. 72, no. 1, p. 1-11.

Food and Agriculture Organization of the United Nations FAO, 2009. Yearbook of fishery statistics: summary tables. Roma: FAO. Available from: www.fao.org. Access in June 27, 2009.

FUNARI, E. and TESTAI, E. 2008. Human health risk assessment related to cyanotoxins exposure. Critical Reviews in Toxicology, vol. 38, p. 97-125.

GONDWE, MJS., GUILDFORD, SJ. and HECKY, RE., 2011. Carbon, nitrogen and phosphorus loadings from tilapia fish cages in Lake Malawi and factors influencing their magnitude. Journal of Great Lakes Research, vol. 37, p. 93-101.

KOROLEFF, F., 1976. Determination of nutrients. In GRASHOF, E. and KREMLING, E. (Ed.). Methods of seawater analysis. New York: Verlag Chemie Wenhein. p. 117-181.

KUBITZA, F., 2003. Qualidade de água no cultivo de peixes e camarões. Jundiaí. 229 p.

LACHI, GB. and SIPAÚBA-TAVARES, LH., 2008. Qualidade da água e composição fitoplanctônica de um viveiro de piscicultura utilizado para fins de pesca esportiva e irrigação. Boletim de Instituto de Pesca, vol. 34, p. 29-38.

LIAO, IC., HUANG, TS., TSAI, WS., HSUEH, CM., CHANG, SL. and LEAÑO EM., 2004. Cobia Culture in Taiwan: Current Status and Problems. Aquaculture, vol. 237, p. $155-165$.
MORIARTY, DJW., 1997. The role of micro-organisms in aquaculture ponds. Aquaculture, vol. 151, p. 333-349.

NTENGWE, FW. and EDEMA, MO., 2008. Physico-chemical and microbiological characteristics of water for fish production using small ponds. Physics and Chemistry of the Earth, vol. 33, p. 701-707.

OUTTARA, NI., TEUGELS, GG., N'DOUBA, V. and PHILIPPART, JC., 2003. Aquaculture potential of the blackchinned tilapia, Sarotherodon melanotheron (Cichlidae). Comparative study of the effect of stocking density on growth performance of landlockes and natural populations under cage culture conditions in Lake Ayame (Côte d'Ivoire). Aquaculture Research, vol. 34, p. 1223-1229.

SANTOS, DMS., CRUZ, CF., PEREIRA, DP., ALVES, LMC. and MORAES, FR., 2012. Microbiological water quality and gill histopathology of fish from fish farming in Itapecuru-Mirim County, Maranhão State. Acta Scientiarum, vol. 34, p. 199-205.

SAPKOTA, A., KUCHARSKI, M., BURKE, J., MCKENZIE, S., WALKER, P. and LAWRENCE, R., 2008. Aquaculture practices and potential human health risks: Current knowledge and future priorities. Environment International, vol. 34, p. 1215-26.

SCHENONE, NF., VACKOVA, L. and CIRELLI, AF., 2011. Fish-farming water quality and environmental concerns in Argentina: a regional approach. Aquaculture International, vol. 19. p. 855-863.

SEMYALO, R., ROHRLACK, T., NAGGAWA, C. and NYAKAIRU, WG., 2010. Microcystin concentrations in Nile Tilapia (Oreochromis niloticus) caught from Murchison Bay, Lake Victoria and Lake Mburo: Uganda. Hydrobiologia, vol. 638, p. 235-244.

STRICTAR-PEREIRA, L., AGOSTINHO, AA. and GOMES, LC, 2010. Cage culture with tilapia induces alteration in the diet of natural fish populations: the case of Auchenipterus osteomystax . Brazilian Journal of Biology, vol. 70, p. 1021-1030. 